\title{
PENGARUH KOMPETENSI APARAT DESA, KOMITMEN ORGANISASI DAN PARTISIPASI MASYARAKAT TERHADAP KEBERHASILAN PENGELOLAAN KEUANGAN DESA (Sudi Kasus Desa Buntongi Kec.Ampana Kota Kab.Tojo Una Una)
}

\author{
Siti Aminah H. Karim*, Mahmud Lahay*, Zulfan Monoarfa*, Rosida P. Adam*, \\ Suardi*
}

\begin{abstract}
ABSTRAK
Dalam administrasi pemerintahan dan pembangunan, sumber pendapatan keuangan desa diperlukan sebagi wujud komitmen organisasi pemerintah desa terhadap otoritas, tugas dan tanggung jawab dalam pelaksanaan manajemen keuangan desa yang transparan dan akuntabel. Tujuan dari penelitian ini adalah untuk menentukan dan menganalisis sejauh mana pengaruh kompetensi pejabat desa, komitmen perangkat desa dan partisipasi masyarakat terhadap keberhasilan dalam pengelolaan keuangan desa. Penelitian ini menggunakan metode campuran dengan menggabungkan penelitian kualitatif dan kuantitatif dengan teknik pengambilan sampel jenuh. Jumlah responden sebanyak 40 orang. Analisis yang digunakan dengan menggunakan analisis SWOT dan regresi linier berganda. Hasil penelitian menunjukkan bahwa tingkat probabilitas simultan pejabat desa, komitmen perangkat desa dan partisipasi masyarakat memiliki pengaruh langsung yang signifikan terhadap keberhasilan pengelolaan keuangan desa.
\end{abstract}

Kata kunci: kompetensi pejabat desa, komitmen perangkat desa, partisipasi masyarakat, pengelolaan keuangan desa

\section{ABSTRACT}

In the administration of governance and development, a source of village financial income is needed, for this the organizational commitment of the village government towards the authority, duties and responsibilities of implementing village financial management is transparent and accountable. The purpose of this study was to determine and analyze the extent of the influence of the competence of village officials, organizational commitment and community participation on success in village financial management. This type of research is a mixed method by combining qualitative and quantitative research with sampling techniques by saturated sampling. The number of respondents was 40 people. Analysis tools with SWOT analysis and multiple linear regression. The results showed that the simultaneous probability of village officials, organizational commitment and community participation have a direction of significant influence on the success of village financial management.

Keywords: competence of village officials, organizational commitment, community participation, village financial management

PENDAHULUAN
Pelaksanaan otonomi daerah meskipun konsentrasinya pada kabupaten namun sebenarnya desa adalah pelaksana otonomi 
pada level terkecil yang merupakan esensi kemandirian dalam melaksanakan otonomi. Desa secara administratif merupakan bentuk pemerintahan terkecil yang dipimpin oleh kepala desa dari sebuah pemilihan secara langsung. UU Desa Nomor 6/2014 menegaskan eksistensi desa dengan pengakuan atas kewenangan berdasarkan asal-usul (tradisional) merupakan landasan kuat untuk membentengi hak-hak masyarakat desa agar dapat berdaya menggerakkan inisiatif-inisiatif untuk mengurangi kemiskinan. Wujud dari pemenuhan hak desa untuk menyelenggarakan otonominya agar tumbuh dan berkembang mengikuti pertumbuhan dari desa itu sendiri.

Kendala yang sering terjadi dilapangan (desa) selama ini adalah masalah penyetoran pajak tidak sesuai (Kementerian Keuangan RI, 2016:19).

Kesulitan yang terjadi di desa Buntongi kecamatan Ampana Kota adalah kurangnya koordinasi maksimal antara pihak pelaksana dengan masyarakatnya, hal ini dikarenakan proses awal recruitment aparat desa tidak berdasarkan pada basic pendidikan dan kompetensi yang dimiliki (the right man on the right place) akan tetapi tergantung pada yang dianggap mampu dan mau,serta adanya intervensi dari pihak atas mulai dari kecamatan hingga kabupaten sehingga berdampak sumber daya tidak dapat berkembang. SDM yang tersedia sebagai pelaksana aparatur desa memiliki pendidikan minimal SLTP berdasarkan PERDA Kabupaten Tojo Una Una No.22 Tahun 2008 pasal 13 ayat 3'bahwa setiap warga desa dapat diangkat menjadi pemegang kas desa dengan syarat pendidikan minimal SLTP' merujuk pada PERDA tersebut ditemukan adanya korelasi jenjang pendidikan seseorang dengan kemampuan dan keahlian dalam mengelola keuangan desa sehingga dapat berdampak koordinasi yang kurang maksimal antara pihak pelaksana di desa dengan masyarakatnya, tidak adanya kelengkapan administrasi yang dimiliki oleh desa untuk menunjang kinerja pemerintahan desa, terbatasnya pengetahuan dan keahlian yang dimiliki oleh SDM sebagai aparatur desa sehingga mengakibatkan pengelolaan dan penggunaan anggaran tidak sesuai dengan RAB yang dibuat dan kelebihan perhitungan RAB. Sebagaimana hasil evaluasi secara nasional penggunaan dana desa semester satu tahun 2016 mengalami permasalahan antara lain, penggunaan dana desa diluar bidang prioritas, pengeluaran dana desa tidak didukung dengan bukti yang memadai, pekerjaan konstruksi dilakukan seluruhnya olrh pihak ketiga atau penyedia jasa, kelebihan pembayaran, pemungutan dan pada kurang optimalnya pengelolaan dana keuangan desa dan pelaksanaan program pemerintahan desa.

Desa Buntongi kecamatan Ampana Kota pada tahun 2017 memperoleh pendapatan diluar PADesa yang bersumber Anggaran Pendapatan dan Belanja Negara, dari jumlah dana yang diterima peneliti sangat tertarik untuk mendalami riset ini guna mengetahui sejauhmana kemampuan kepala desa buntongi dapat melaksanakan roda pemerintahan desa dengan tugas dan tanggung jawab besar yang hanya berlatar belakang pendidikan SLTP, sedangkan masalah yang ada meliputi persoalan pengembangan wilayah, ekonomi dan sosial budaya guna mewujudkan tata kelola pemerintahan yang baik (Good Governance).

\section{METODE PENELITIAN}

Penelitian ini menggunakan metode campuran (mixed method) dengan desain exploratory sequential design yaitu suatu langkah penelitian dengan menggabungkan dua bentuk pendekatan dalam penelitian 
yaitu kualitatif dan kuantitatif (cresswel, 2010:5). Hal ini dilakukan untuk menemukan permasalahan dilapangan yang akan memberikan pemahaman baru bagi aparatur desa dalam melaksanakan pemerintah desa sebagai opsi untuk penyelesaian masalah, pendekatan ini digunakan dengan tingkat sepadan untuk memahami sebuah pengaruh tingkat pendidikan atau kompetensi aparat desa, komitmen organisasi dan partisipasi masyarakat terhadap keberhasilan pengelolaan keuangan desa.

Sedangkan metode kuantitatif yaitu untuk mengetahui pentingnya kompetensi aparatur desa, komitmen organisasi dan partisipasi masyarakat terhadap keberhasilan pengelolaan keuangan desa. Tehnik pengumpulan data adalah sequential mixed method dengan metode wawancara, metode skala dan metode observasi, dengan jumlah responden 40 orang. Analisis data yang digunakan Analisis SWOT menunjukkan gambaran deskriptif tentang suatu kiat untuk beberapa stakeholder untuk pengambilan keputusan beberapa fasilitas saat sekarang atau kedepan pada kualitas internal maupun eksternal, serta ukuran apa sajakah yang dipakai untuk menilai kesuksesan manajemen dalam menggerakkan misi untuk wujudkan visinya. Serta analisis regresi linier berganda (Sugiyono, 2012;18) dengan rumus :

$Y^{\wedge}=a+\beta_{1} X_{1}+\beta_{2} X_{2}+\beta_{3} X_{3}+e$

Dimana ;

$\mathrm{Y}^{\wedge}=$ keberhasilan pengelolaan keuangan desa

$\mathrm{a}=$ lintersep (konstanta)

$\beta_{1} \beta_{2} \beta^{3}=$ koefisien regresi

$\mathrm{x}_{1}=$ Kompetensi aparat desa

$$
\begin{array}{ll}
\mathrm{x}_{2} & =\text { komitmen organisasi } \\
\mathrm{x}_{3} & =\text { partisipasi masyarakat } \\
\mathrm{e} & =\text { variable gangguan atau } \\
& \text { kesalahan }
\end{array}
$$

\section{HASIL DAN PEMBAHASAN}

Pemerintahan desa Buntongi kecamatan Ampana Kota merupakan desa pemekaran dari desa sansarino,dengan jumlah penduduk 1.068 jiwa 302 kepala keluarga (sumber:desa 2017) koordinator pemerintahan desa dipimpin oleh seorang kepala desa. Secara struktural lembaga pemerintahan desa Buntongi berjumlah 10 orang terdiri dari 1 orang kepala desa, 1 orang sekertaris desa, 3 orang kepala seksi, 3 orang kaur dan 2 orang kepala dusun, yang masing-masing mempunyai latar belakang pendidikan terendah adalah SLTP dan SLTA. Apabila kita meninjau tugas dan tanggungjawab yang diembannya begitu besar dengan beberapa prioritas masalah yang ada dibutuhkan SDM yang berkompeten dibidangnya.

Menurut Goggin', jumlah SDM yang dimiliki organisasi yang diberi mandat untuk mengimplementasikan suatu kebijakan akan mempengaruhi kapasitas organisasi tersebut dalam menjalankan misinya untuk mewujudkan tujuan organisasi. Dalam menjalankan tugas pokok dan fungsi aparat Desa Buntongi Kecamatan Ampana Kota Kabupaten Tojo Una Una, terdapat permasalahn yang dihadapi baik internal maupun eksternal dapat mempengaruhi peningkatan kinerja aparat desa, dimana faktor tersebut dapat menjadi suatu kekuatan maupun kelemahan dalam organisasi lembaga pemerintahan desa. Unsur kekuatan yang dapat dijadikan kelebihan dari aparatur desa adalah bahwa program pemerintah desa Buntongi secara kelembagaan dilakukan bersinergi dan 
berorientasi secara berjenjang dengan pemerintah kabupaten Tojo Una Una serta terjalin kerja sama dengan pemerintah kabupaten guna melaksanakan tugas pokok dan fungsi dengan baik dalam mengelola keuangan desa. Sedangkan kelemahan dari aparatur desa buntongi, adalah :

1. kurangnya SDM yang berkompeten dibidangnya;

2. kurangnya database perkembangan desa sebagai bahan perencanaan;

3. Belum optimalnya prasarana pendukung untuk melaksanakan Tupoksi secara komputerisasi.

Selanjutnya permasalahan yang dihadapi dibidang pemberdayaan masyarakat yaitu masih kurangnya pemahaman masyarakat dalam pengelolaan bantuan-bantuan yang diberikan oleh pemerintah desa dalam hal peningkatan ekonomi masyarakat, pembinaan serta sosialisasi secara bertahap kepada masyarakat. Desa dalam kaitannya dengan SDM yang berkompeten dibidangnya.

Hasil Pengujian Hipotesis dan perhitungan diperoleh $\mathrm{F}$ hitung $=56,738$, yang menunjukkan bahwa nilai signifikansi variable dependent mempunyai pengaruh terhadap variable independent yang bermakna bahwa keberhasilan pengelolaan keuangan desa di Desa Buntongi dapat tercapai bila didukung dengan kompetensi aparat, komitmen organisasi dan partisipasi masyarakat, kepercayaan diri dalam implementasi, penggunaan anggaran dan penyajian laporan keuangan secara transparan dan akuntabel guna menunjang pembangunan desa. Tuannakotta (2014) menyatakan faktor penyebab terjadinya kecurangan tidak terlepas dari konsep segitiga kecurangan, yaitu tekanan, kesempatan (peluang) dan rasionalisasi.

Berdasarkan hasil regresi, variable yang paling dominan pengaruhnya terhadap keberhasilan pengelolaan keuangan desa adalah kompetensi aparat desa dan komitmen organisasi bersama-sama sebesar $36,1 \%$. Hal ini menunjukkan bahwa kompetensi aparat desa dan komitmen organisasi merupakan faktor penting dalam mengelola keuangan desa. Profesi telah menetapkan standar yang tinggi bagi siapapun yang ingin menjadi aparatur desa, dengan kata lain tidak tawar menawar berkaitan dengan kualitas yang telah distandarkan, dengan kata lain lebih baik memiliki jumlah aparat yang terbatas dan kompeten dari pada memiliki jumlah yang banyak tetapi kualitas yang dimiliki dibawah standar persyaratan teknis dan analisis yang memadai. Oleh karena itu adalah kewajiban dan kewenangan dari pemerintah daerah kabupaten Tojo Una Una untuk menetapkan atribut-atribut pengetahuan, kemampuan teknis dan analisis, serta karakter kualitas pada pemilihan dan pengembangan aparatur desa dilingkungan pemerintah Kabupaten Tojo Una Una.

Adanya pengaruh tersebut karena kompetensi mempunyai kemampuan dalam mengembangkan ilmu yang dimiliki, oleh karena itu kompetensi dalam bidang keuangan guna meningkatkan akuntabilitas laporan keuangan, mulai dari tahap pencatatan, pengalokasian dana anggaran sampai pada tahap penyajian laporan keuangan, sehingga penilitian ini mengindikasikan bahwa dengan keterbatasan pendidikan yang dimilki oleh aparatur desa, akan berdampak pada hasil penyajian dan pelaporan keuangan, alhasil dilapangan ditemukan adanya ketidak sesuaian pencatatan dan penghitungan volume pekerjaan dengan besaran nilai biaya yang dikeluarkan. Hal ini dikarenakan kurangnya ketelitian serta pemahaman terhadap alokasi biaya-biaya yang digunakan dan dipandang perlu adanya 
pengawasan ketat dari pemerintah daerah guna menghindari penyelewengan yang tidak diinginkan dapat menumbuhkan kepercayaan pada diri sendiri dan dapat menyusaikan diri dengan lingkungan social. Orang yang berpendidikan akan lebih rasional dalan berpikir dan bertindak serta memahami tugas dan tanggung jawab yang dibebankan kepadanya sehingga dapat melaksanakan tugas dan tanggung jawab tersebut dengan baik, semakin tinggi pendidikan yang ditempuh, baik secara formal maupun non-formal sesuai bidang pekerjaan maka semakin tinggi pula pengalaman intelektual yang dimiliki

Hasil penelitian Bappenas (2002) tingkat pemahaman aparatur pemerintah yang sarjana lebih tinggi dari pada tingkat pemahaman aparatur pemerintah yang berpendidikan SMU dan tingkat pemahaman aparatur pemerintah yang berpendidikan pasca sarjana lebih tinggi dari tingkat pemahaman aparatur pemerintah yang sumber daya manusia yang berkualitas dengan pendidikan yang tinggi akan mampu membantu karyawan dalam menyelesaikan tugas terutama tugas pengelolaan keuangan. Meskipun demikian, sebagian besar pegawai mengakui adanya ketidaksesuaian antara latar belakang pendidikan formal yang dimiliki dengan tugas mereka sebagai aparatur desa. Hasil penelitian ini juga mengungkapkan bahwa aparatur desa memiliki latar belakang pendidikan yang beragam. Salah seorang pegawai keuangan menyatakan bahwa pekerjaan sebagai aparatur desa bagian keuangan hendaknya diberikan kepada mereka yang berlatar belakang pendidikan akuntansi agar lebih mudah memahami tentang pengelolaan keuangan dan penyusunan laporan. Beberapa penelitian sebelumnya Syarifuddin (2017), menyatakan bahwa dibutuhkan kesiapan pemerintah desa dalam pelaksanaan pengelolaan dana desa salah satu yang perlu diperhatikan adalah komitmen. Adanya komitmen organisasi diharapkan dapat mendukung pengelolaan desa sehingga mampu melaksanakan program dengan baik. Keberhasilan pengelolaan dana desa secara akuntabel dilaksanakan oleh pemerintah sebagai wujud komitmen pemerintah desa.

\section{Partisipasi masyarakat terhadap keberhasilan Aparatur desa dalam mengelola keuangan desa}

Berdasarkan hasil uji statistic menunjukkan bahwa partisipasi masyarakat memberikan pengaruh yang signifikan terhadap keberhasilan pengelolaan keuangan desa,hasil perhitungannya bahwa nilai koefisien regresi sebesar 0,290 , sementara tingkat signifikansi t sebesar 0,003 $<0,05$, pada taraf kepercayaan 95\%. Hasil ini memberikan gambaran bahwa turut serta masyarakat dalam berpartisipasi dalam setiap kegiatan desa terhadap keberhasilan dan pembangunan desa akan berimplikasi pada berpendidikan sarjana. Hasil penelitian Cahyadi (2009) juga menyimpulkan bahwa banyaknya hasil yang diperoleh dalam pelaksanaan pembangunan baik secara fisik maupun non fisik. Peranan masyarakat dalam penyelenggaraan kegiatan pemerintahan akan memudahkan pemerintah dalam menyelesaikan tugas dan kewajibannya selaku aparatur desa untuk dapat terlibat dalam pengambilan keputusan dan merupakan indicator yang cukup penting. Meskipun demikian, hasil penelitian mengungkapkan bahwa variabel yang paling kecil pengaruhnya terhadap keberhasilan pengelolaan keuangan desa adalah partisipasi masyarakat yaitu $29,0 \%$. $\mathrm{Hal}$ ini mengindikasikan bahwa kemungkinan aparatur desa beranggapan partisipasi masyarakat tidak terlalu penting dari kedua variable lainnya karena partisipasi masyarakat bukanlah yang utama. 


\section{KESIMPULAN DAN SARAN}

\section{Kesimpulan}

Berdasarkan PERDA Kabupaten Tojo Una Una No.22 Tahun 2008 tentang Pengurusan dan Pengelolaan Kekayaan Desa pasal 13 ayat ' 3 ' bahwa setiap warga desa dapat diangkat menjadi pemegang kas desa dengan syarat Pendidikan minimal SLTP. Merujuk pada Perda tersebut peneliti menemukan adanya pengaruh yang signifikan terhadap jenjang pendidikan serta kemampuan dan keahlian yang dimiliki dalam mengelola keuangan desa sehingga dipandang perlu untuk dilakukan peninjauan kembali.

Permasalahan yang terjadi dilapangan selama ini yaitu masalah koordinasi yang kurang maksimal antara pihak pelaksana di desa dengan masyarakatnya. Hal ini dikarenakan proses awal rekruitmen aparat desa tidak berdasarkan pada latar belakang pendidikan dan kompetensi yang dimilki seseorang, akan tetapi bergantung pada yang dianggap mampu. Selanjutnya adanya intervensi dari pihak atas mulai dari kecamatan hingga kabupaten yang mengakibatkan Sumber Daya Manusia tidak dapat berkembang.

Perkembangan situasi desa Buntongi saat ini, terkait rencana pembangunan sejahtera dengan penjelasan bahwa desa yang mandiri berbasis sumber daya local mengandung pengertian bahwa masyarakat desa buntongi masih maju dengan mengandalkan kemampuan dan kekuatan sendiri yang berbasis pada keunggulan sumber daya local secara luas, namun kenyataannya pembangunan desa belum terlaksana $100 \%$, salah satu factor utamanya yaitu tidak tersedianya SDM yang kompeten dibidangnya dan minimnya pengetahuan dan kemampuan yang merupakan indikator dari kompetensi perangkat desa.

\section{Saran}

Perlu adanya pendidikan dan pelatihan yang berkelanjutan serta berkesesuaian dengan tugas-tugas aparatur desa yang menitikberatkan pada pemahaman teoritis mengenai regulasi Standar Akuntansi, sehingga dalam penyajian laporan yang akuntabel.

1. Perlu adanya Lembaga atau aparat yang terikat dan bertugas sebagai internal control dalam mengawasi jalannya pelaksanaan pengelolaan keuangan desa.

2. Pemerintah Daerah Bersama Pemerintah desa perlu mensosialisasikan pentingnya keterlibatan masyarakat dalam proses pengelolaan keuangan desa buntongi kecamatan ampana kota

3. Perlu adanya komitmen dari kepala desa dalam upaya peningkatan kualitas Sumber Daya Manusia (SDM) dalam hal penambahan pengetahuan dan Pendidikan setiap aparatur desa.

\section{DAFTAR PUSTAKA}

Ahmad,Yusran, 2012. Implementasi Kebijakan Alokasi Dana Desa di kecamatan tanasitolo Kab.wajo.

Creswell, John W. 2009. Reserach Design; Qualitative,Quantitative, and Mixed Methods Approaches. $3^{\text {rd }}$ ed, sage Pub.Inc, California.

Danish, R. Q., Y., Kausar, A., and Jabbar, M. 2014. Impact of change Culture and organizational learning. Review of Contemporary Business Research, vol. 3(1), pp. 115-126.

Elgia, Astuty dan Eva, Hany, Fanida, 2012. Akuntabilitas Pemerintah Desa Dalam Pengelolaan APBD Desa (Studi pada Desa serang Kec. Geger Kab. Madiun. Jurnal Riset Akuntansi dan Keuangan Universitas Jember.

Ferina, Ika sasti. 2016. Tinjauan Kesiapan Pemerintah Desa dalam 
Implementasi Peraturan Menteri dalam Negeri No.113 Tentang Pengelolaan Keuangan Desa (studi kasus pada pemdes di Kabupaten Ogan Hiliir. Jurnal Manajemen dan Bisnis.

Halim, Abdul. 2012. Akuntansi Keuangan Daerah. Penerbit Salemba Empat. Jakarta.

Handoko, Hani, T. 2013. Manajemen Sumber Daya Manusia. Edisi Revisi. Penerbit BPFE. Yogyakarta.

Indrianto, Nur dan Bambang, Supomo. 2013. Metodologi Penelitian Bisnis untuk Akuntansi dan Manajemen. Penerbit BPFE. Yogyakarta.

Lembaga Administrasi Negara dan Badan Pengawasan Keuangan dan Pembangunan RI. 2008. "Akuntabilitas governance: Modul Sosialisasi system Akuntabilitas Kinerja Instansi Pemerintah (AKIP) LAN BPKP RI”. Jakarta.
Nurlan, Darise. 2012. Pengelolaan Keuangan Daerah. Penerbit Indeks. Jakarta.

Peraturan Menteri Dalam Negeri No.37 Tahun 2007 Tentang Pedoman Pengelolaan Keuangan Desa.

Peraturan Pemerintah RI UU No. 6 Tahun 2014 Tentang Desa.

Peraturan Menteri Dalam Negeri RI No. 113 Tahun 2014 Tentang Pengelolaan Keuangan Desa.

Singh,shamshir \& Kaur Ranjit . 2015. Good Governance; Expectations and challenges. International journal of applied research.1 (11); pp: 114-121.

Walker,Richard M \& Andrews. 2015. Local Government Management and performance; A Review of Eevidence. Journal of public Administration Research and theory, vol 25, issue 1:101-153.

*Dosen SKU Universitas Tadulako

(Email: Sitiaminahsiti101@gmail.com) 